\title{
Educating for Good Questioning: a Tool for Intellectual Virtues Education
}

\author{
Lani Watson ${ }^{1}$
}

Received: 20 September 2017 / Accepted: 9 April 2018 /Published online: 13 June 2018

(C) The Author(s) 2018

\begin{abstract}
Questioning is a familiar, everyday practice which we use, often unreflectively, in order to gather information, communicate with each other, and advance our inquiries. Yet, not all questions are equally effective and not all questioners are equally adept. Being a good questioner requires a degree of proficiency and judgment, both in determining what to ask and in deciding who, where, when, and how to ask. Good questioning is an intellectual skill. Given its ubiquity and significance, it is an intellectual skill that, I believe, we should educate for. In this paper, I present a central line of argument in support of educating for good questioning, namely, that it plays an important role in the formation of an individual's intellectual character and can thereby serve as a valuable pedagogical tool for intellectual character education. I argue that good questioning plays two important roles in the cultivation of intellectual character: good questioning (1) stimulates intellectually virtuous inquiry and (2) contributes to the development of several of the individual intellectual virtues. Insofar as the cultivation of intellectually virtuous character is a desirable educational objective, we should educate for good questioning.
\end{abstract}

Questioning is a familiar, everyday practice. We ask questions from an early age in order to gather and exchange information, to communicate our needs and desires, to engage others in conversation, and to advance both our public and private inquiries. Questioning, in short, is an essential component of our collective, social, and intellectual endeavours. Yet, not all questions are equally effective and not all questioners are equally adept at achieving these ends. Being a good questioner requires a degree of proficiency and judgement, both in determining what to ask and in deciding who, where, when, and how to ask. Good questioning is an intellectual skill. Given its ubiquity and personal and societal significance, it is an intellectual skill that, I believe, we should educate for. In this paper, I present a central line of argument in support of educating for good questioning, namely, that it plays an important role in the formation of an individual's intellectual character. Educating for the

Lani Watson

Lani.watson@ed.ac.uk

1 School of PPLS, University of Edinburgh, Room 5.05, 3 Charles Street, Edinburgh EH8 9AD, UK 
skill of good questioning, therefore, serves as a valuable pedagogical tool for intellectual character education. I argue that the intellectual skill of good questioning plays two important and closely related roles in the formation of intellectual character. Firstly, good questioning stimulates intellectually virtuous inquiry. Secondly, good questioning contributes to the development of several of the individual intellectual virtues. As such, the skill of good questioning contributes to the formation of intellectually virtuous character as a whole. Insofar as the development of intellectually virtuous character is a desirable educational objective, we should educate for good questioning. ${ }^{1}$

\section{Intellectual Skill and Intellectual Virtue}

To begin, a discussion of intellectual skills, intellectual virtues, and the relationship between them will be helpful. I take the terms 'intellectual skills' and 'intellectual virtues' to refer to distinct subsets of two larger domains, namely, the domains of skill and virtue. Characterising intellectual skills and intellectual virtues is, therefore, largely a matter of characterising skills and virtues simpliciter. Where this challenge arises, in both virtue ethics and virtue epistemology, it is often helpfully framed by a discussion of the distinction between skills and virtues. By clarifying this distinction, authors seek to define the nature of skills and virtues themselves (Foot 1978; Wallace 1978; Meilaender 1984; Broadie 1991; Zagzebski 1996; Baehr 2011). Whilst there is not space to examine the distinction in detail here, two key differences between skills and virtues are worth noting. Firstly, skills need not be exercised in order to be properly considered skills, whereas virtues must be exercised, under the appropriate circumstances, in order to be considered virtues (Foot 1978; Meilaender 1984; Zagzebski 1996). A skilled pianist, for example, may stop playing the piano and still retain her skill, whereas an honest man who stops telling the truth (under the appropriate circumstances) can no longer be considered honest. Secondly, the exercise of skill does not require a person to have any particular motivation, whereas the exercise of virtue requires that a person be virtuously motivated (Montmarquet 1992; Zagzebski 1996; Baehr 2011). The skilled pianist who plays purely for financial gain is still a skilled pianist, whereas the honest man who is motivated to tell the truth purely for financial gain will not (under most circumstances) be considered virtuously honest.

These two key differences point towards a more general distinction between skills and virtues: virtues are characterological, and skills are not. Put another way, virtues constitute praiseworthy features of a person's character, whilst skills constitute praiseworthy features of a person's actions or endeavours. As Jason Baehr (2011) observes, 'intellectual skills are not personal in the way that intellectual virtues are' (p. 30). We do not, for example, learn anything (for certain) about a person's character, merely by learning that she is a skilled pianist, whereas learning that a man is virtuously honest necessarily tells us that he has an honest character. In short, we speak of virtuous, but not skilled character. This distinction between skills and virtues is worth bearing in mind for the following discussion. ${ }^{2}$

\footnotetext{
${ }^{1}$ I do not offer a defence of intellectual character education in this paper. For compelling arguments in support of this approach, see Hare 2003, Battaly 2006, and Baehr 2011, 2013, 2016. For some early critical comments, see Missimer 1990.

${ }^{2}$ For a more detailed discussion on the nature of skills and virtues, see Linda Zagzebski's Virtues of the Mind (Zagzebski 1996, pp. 106-116) and Jason Baehr's The Inquiring Mind (Baehr 2011, pp. 17-32). For an overview of further relevant work in virtue epistemology, see Battaly 2008.
} 
What makes a particular skill or virtue distinctively intellectual is a further challenge faced by virtue epistemologists concerned with defining the intellectual skills and virtues. Linda Zagzebski (1996), for example, argues that the 'Intellectual virtues are best viewed as a form of moral virtue' (p. 139). In contrast, Julia Driver (2000, 2003) argues against the conflation of the moral and intellectual virtues, citing cases in which the two appear incompatible. Baehr (2011) attempts to define a middle ground between these two positions (pp. 206-222). As defining the intellectual skills and virtues is not the focus of this paper, it will suffice to take the identification of distinctively intellectual skills and virtues as a useful, if imperfect means of carving up the undeniably complex terrain comprising the various domains of human experience. More significant, for present purposes, is the relationship between the intellectual skills and the intellectual virtues. Here, I follow authors such as Zagzebski (1996) and Roberts and Wood (2007) in taking the intellectual virtues to be importantly related to and partly constituted by intellectual skills: part of what it is to be intellectually virtuous is to possess and exhibit certain intellectual skills. Zagzebski, for example, writes, 'Skills serve virtues by allowing a person who is virtuously motivated to be effective in action' (p. 113). Given that effectively exercising one's intellectual virtues, under the appropriate circumstances, is a requirement of being intellectually virtuous, on Zagzebski's account of the virtues, intellectual skill is thereby necessary, but not sufficient, for intellectual virtue. Similarly, Roberts and Wood (2007) maintain that 'all virtues bear some relation or other to skills by which we negotiate generically human activities' (p. 59). The intellectual skills one requires in order to be intellectually virtuous will, of course, vary depending on the intellectual virtue(s) in question. Perspective-taking, for example, is an intellectual skill plausibly required in order to be virtuously open-minded (Riggs 2010; Baehr 2011). The ability to maintain focus is an intellectual skill plausibly integral to intellectual perseverance. Zagzebski (1996) identifies 'perceptual acuity' as an intellectual skill closely associated with intellectual thoroughness and care (p. 114). In each case, the exercise of intellectual virtue requires the exercise of intellectual skill.

This close relationship between intellectual skills and intellectual virtues can be traced back to the Aristotelian account of the virtues in which the intellectual virtues are seen to require a degree of skill that is learned or cultivated (Nicomachean Ethics, II.1, Aristotle 2011). Indeed, it is skill, at least in part, that distinguishes the virtuous from the nonvirtuous. A person may be virtuously motivated and yet fail to possess intellectual virtue because they lack the intellectual skill required to act virtuously under the appropriate circumstances. A person may be non-virtuously open-minded, for example, by failing to make appropriate judgements about whose perspective to take in a given situation. If I assign equal weight to the perspectives of a seasoned detective and her three-year-old child at the scene of a crime, I am arguably exhibiting a non-virtuous kind of open-mindedness. Virtuous open-mindedness requires a greater degree of skill and judgement. Educating for intellectual skill is, therefore, an essential aspect of educating for intellectual virtue. It is unsurprisingly from the Aristotelian tradition also that the idea of educating for the intellectual virtues arises. Aristotle writes, 'Both the coming-into-being and increase of intellectual virtue result mostly from teaching' (Nicomachean Ethics, II.1, Aristotle 2011). Indeed, it is at least in part because the intellectual virtues require a degree of skill in order to be intellectual virtues that they find a natural home in an educational environment where skills can be taught and practiced. The teaching of intellectual skills, in general, can be viewed as a crucial stage in the cultivation of intellectually virtuous character. In what follows, I argue that good questioning is one of the key intellectual skills to educate for in 
order to cultivate intellectually virtuous character. I first offer some remarks on the intellectual skill of good questioning.

\section{Good Questioning as an Intellectual Skill}

Questioning can be broadly characterised as an intellectual skill, alongside numerous other activities such as reading, counting, deducing, solving equations, playing chess, doing crosswords, and so on. As noted, determining why each of these is a distinctively intellectual skill is not the focus of the present discussion. It will suffice to think of the label 'intellectual' as an imprecise but useful means of distinguishing intellectual skills from other types of skills (for example, 'physical' skills, such as hitting a baseball or dancing a pirouette). Note, however, that unlike reading or counting, good questioning is a complex intellectual skill in the sense that it will frequently involve the exercise of prudential, and moral judgements, alongside intellectual ones. In this regard, good questioning is akin to similarly complex intellectual skills such as argumentation. Good argumentation can be characterised by a broadly intellectual goal, namely that of persuading others of the truth, merits, feasibility, and so on, of a particular conclusion. In order to achieve this goal, the good arguer may find herself drawing on a range of intellectual, prudential, and moral resources. She may, for example, choose to present her argument just after lunch when her audience is happy and thereby more likely to accept her conclusion. Or she may emphasise the affective dimensions of her argument in order to produce an emotional response that will lead the audience to favour her conclusion. These prudential and moral judgements form part of the skill of good argumentation vis-à-vis the goal of persuading others of the truth, merits, feasibility, and so on, of a particular conclusion. The intellectual skill of good argumentation extends beyond the mechanics of constructing a valid set of inferences from premises to conclusion. A valid set of inferences may be thought of as a 'good argument', in some sense, but good argumentation is more than this. It is a rich and complex intellectual skill embedded within a social context.

Likewise, the intellectual skill of good questioning is embedded within a social context and is governed by a set of societal and self-generating norms. Appreciating this social context is essential to understanding good questioning as an intellectual skill. It too can be characterised by a broadly intellectual goal, namely that of eliciting information. In order to achieve this goal, the good questioner may find herself drawing on a range of intellectual, prudential, and moral resources. She may, for example, choose to ask her question at a particularly convenient time when she knows she will be more likely to get the information she needs. Or she may decide that one person rather than another will be more likely to provide her with the information she needs, based on any number of judgements spanning the intellectual, moral, and prudential domains. These judgements form part of the skill of good questioning vis-à-vis the goal of eliciting information. We will examine this goal in more detail in due course. For now, it is helpful to draw attention to the contextual features of good questioning as an intellectual skill. These contextual features reveal that the skill of good questioning extends beyond the mechanics of constructing an interrogative sentence that expresses a desire for this or that piece of information. Such a sentence may be thought of as a 'good question', in some (limited) sense, but good questioning is more than this. It 
requires the questioner to make appropriate judgements about how to acquire the information that she needs or wants. Like good argumentation, good questioning is a rich and complex intellectual skill.

For any type of skill, a person can be better or worse at executing it. Moreover, a person's level of skill, in any domain, is a matter of degree. Indeed, the spectrum is such that at one extreme end of it, a person may no longer be counted as exhibiting any skill at all. If a person is a very poor reader, for example, then she may not count as performing an intellectual skill, but rather as attempting and failing to do so. In this case, we might regard the person as engaging in an intellectual activity, rather than exhibiting an intellectual skill. It nonetheless seems right to say that an activity, such as reading, is at least sometimes an intellectual skill that one can fail to exhibit, or be better or worse at: more or less skilled. Likewise, questioning is an intellectual skill that one can be better or worse at. If a person is a very poor questioner, we might say that she is engaging in an intellectual activity, but not exhibiting an intellectual skill. Alternatively, we might say that she is attempting and failing to exhibit an intellectual skill. At any rate, when characterised as an intellectual skill, questioning, like any other skill, can be more, or less skilled, by a matter of degree.

What makes questioning more or less skilled? Put another way, what makes questioning good or bad?

Before answering this, it is worth highlighting the sense of 'good' in operation in the question. This is the sense which typically attaches to the exercise of a skill, for example, when one speaks of a good driver or a good juggler. This sense of good is distinctively non-moral. It attaches equally to the exercise of complex intellectual skills such as good argumentation and good questioning. One may emphasise the affective dimensions of a line of argument in a particularly distasteful or manipulative way, for example, and still achieve the goal of persuading others of its conclusion. Thus, one may be a good arguer qua intellectual skill, that is, good at achieving the intellectual goal of argumentation, without being good in any moral sense. Similarly, one may ask hurtful or embarrassing questions and still achieve the goal of eliciting the information one is after. Thus, one may be a good questioner qua intellectual skill, that is, good at eliciting information, without being good in any moral sense. Herein, the distinction between intellectual skills and intellectual virtues is again manifest: intellectual skills do not require virtuous motivations. What, then, makes questioning good as an intellectual skill?

Here, we can return to an examination of the characteristic goal of questioning, namely, that of eliciting information. ${ }^{3}$ Questions are, in essence, information-eliciting acts. A person can be more or less skilled at performing such acts, and accordingly, they will be a more or less skilled questioner. The intellectual skill of good questioning arises when a person not only acts in order to elicit information, but acts competently in order to elicit worthwhile information. I offer a more detailed account of good questioning elsewhere (Watson, Educating for Good Questioning as a Democratic Skill, forthcoming), so I will provide a condensed version here: the good questioner

\footnotetext{
${ }^{3}$ Note the contrast between 'eliciting' information and alternatives such as 'gathering' or 'acquiring' information. This is significant insofar as one thinks of gathering or acquiring something as implying that it is not something that one already has. In contrast, one can elicit information, on behalf of another, even when one already has the information oneself. Teachers are often engaged in this activity, asking questions to which they already know the answer, in order to elicit information that their students do not yet have. Thus the goal of questioning is best characterised as eliciting rather than gathering or acquiring information.
} 
acts competently in order to elicit worthwhile information. A questioner acts competently when she makes appropriate judgements about who, when, where, and how to elicit information: the good questioner asks the right questions, of the right information source(s), at the right time and place. It is here that the contextual features of good questioning are most apparent. I may know what information I need but be a poor judge of who to ask in order to elicit that information. Asking a detective's three-year-old daughter if she has checked for fingerprints at the scene of a crime would be an instance of questioning gone awry not because the question itself is flawed, but because my judgement about who will be able to provide me with the information is. In this case, I am failing to achieve the goal of good questioning, namely, eliciting information, due to a faulty judgement on my part, and so I am failing to exercise the intellectual skill of good questioning.

A questioner elicits worthwhile information when she makes appropriate judgements about what information to elicit: the good questioner avoids eliciting trivial or disvaluable information and elicits information that is relevant or significant given her aims and context. Asking a detective at the scene of a crime what she had for lunch, rather than whether she has checked for fingerprints, would reflect poor judgement about what to ask, rather than who (assuming that information about the detective's lunch is irrelevant to the investigation). In this case, I am again failing to achieve the goal of good questioning, namely, eliciting information, due to a faulty judgement on my part, and so I am failing to exercise the intellectual skill of good questioning. Here again, the contextual features of good questioning play a role. Indeed, these apparently distinct conditions for good questioning-competency and worthiness - are often closely related, if not fully interdependent, in real-world situations. One may not, for example, be able to determine what to ask without also determining who to ask. If the only person to ask at the scene of a crime is a detective's three-year-old daughter, I should adjust the information that I attempt to elicit to reflect this. Of course, in either case, one may fail to elicit information due to some factor outside one's control, in which case one would not be failing to exhibit the skill of good questioning. Successfully eliciting information is not a requirement for good questioning; acting competently in order to elicit worthwhile information is. It is in virtue of satisfying these conditions that the questioner transforms the activity of questioning into the skill of good questioning. The good questioner acts competently in order to elicit worthwhile information.

Good questioning, then, is an intellectual skill that allows us to elicit information. It enables us to effectively navigate our informational environment in order to identify and access the information that we need or want in a given situation. There are, of course, multiple reasons why one might employ this skill and multiple uses for the information once acquired. Given this, one might think that information eliciting is not the proper or only goal of good questioning. One might ask questions in order to express care or concern, for example, or to disrupt a process or humiliate a colleague or for any number of other reasons where information eliciting is not the conscious, explicit, or ultimate aim. In each of these cases, however, information eliciting is still the common factor. When I express care for a friend by asking him how he is feeling, I do so by means of an information-eliciting act, by asking a question. I could choose to express care by giving him a hug instead. But when I do so by asking a question, I express a desire for information and it is this that does the work of showing him that I 
care, even when the information itself is not my conscious, explicit, or ultimate aim. Similarly, if I attempt to humiliate a colleague by asking him in public why he can't tie his shoelaces properly, I do so by means of an information eliciting act, by asking a question. I could have chosen to point at his shoelaces and laugh loudly in order to achieve the same humiliating effect. But if I choose to ask a question, I achieve this effect by expressing a desire for information and it is this that does the work of humiliating him, even when the information itself is not my conscious, explicit, or ultimate aim. With respect to the norms that govern the practice, the goal of questioning is always information-elicitation. Likewise for the intellectual skill of good questioning. The good questioner acts competently in order to elicit worthwhile information. Having provided in outline a characterisation of good questioning as an intellectual skill, we may now return to the central question: why should we educate for good questioning? In particular, how does good questioning stimulate intellectually virtuous inquiry and contribute to the development of intellectually virtuous character?

\section{Good Questioning and Intellectually Virtuous Inquiry}

The argument that good questioning stimulates intellectually virtuous inquiry is not, in essence, a difficult one to make. Questioning, as an activity in general, often marks the beginning of inquiry, which involves both the asking and answering of questions. Indeed, the initiation of inquiry could be viewed as one of the most conspicuous and essential roles that questioning plays in our daily lives. Simply in virtue of its role in initiating inquiry, questioning generates opportunities for intellectually virtuous inquiry: if there are fewer inquiries overall, there will more than likely be fewer intellectually virtuous inquiries. The good questioner, moreover, elicits worthwhile information in a competent manner and in doing so not only generates opportunities for intellectually virtuous inquiry, but increases the likelihood of an inquiry being intellectually virtuous. By ensuring that the subject of an inquiry is worthwhile, for example, the good questioner helps to avoid the pursuit of trivial or disvaluable lines of inquiry. Asking a detective at the scene of a crime what she had for lunch (instead of, say, whether she has checked for fingerprints) would be an instance of bad questioning initiating nonintellectually virtuous inquiry. This is due to the pursuit of 'the wrong' information (given one's aims and context). Likewise, hours spent inquiring after the number of motes of dust on one's desk (Grimm 2008), rather than, say, tracking down important information on behalf of a student, would be an instance of bad questioning initiating non-intellectually virtuous inquiry. The good questioner guards against initiating such inquiries by identifying the most worthwhile information to elicit given her aims and context. Similarly, by ensuring that an inquiry is initiated and conducted competently, the good questioner helps to reduce the likelihood of inquiry going astray, even when worthwhile information is being pursued. Asking a detective's three-year-old daughter if she has checked for fingerprints at the scene of a crime would be an instance of bad questioning initiating non-intellectually virtuous inquiry. This is due to poor judgement about how to go about eliciting the information. The good questioner guards against initiating such inquiries by identifying effective ways to elicit information in a particular context (for example, by asking the detective instead of her daughter). 
In addition, questioning not only initiates but also guides and shapes inquiry. The questions that are asked once an inquiry has begun determine what information is pursued at each stage and how one goes about eliciting that information. If I continue my line of inquiry regarding the state of the crime scene with the detective's three-yearold daughter, instead of with the detective, I will no doubt end up conducting a drastically different, and less effective, inquiry. It is precisely the skill involved in good questioning - in identifying what, when, where, who, and how to ask - that enables the good questioner to guard against common questioning pitfalls throughout inquiry: asking for the wrong information, from the wrong source, in the wrong way, and so on can, in any number of ways, divert or impede the initiation and progress of intellectually virtuous inquiry. Good questioning, on the other hand, increases the likelihood and facilitates the progress of intellectually virtuous inquiry.

The role that good questioning plays in initiating and guiding intellectually virtuous inquiry is as significant in the classroom as it is elsewhere. Without good questioning, opportunities for intellectually virtuous inquiry in the classroom will be less prevalent and inquiry that does take place will be more likely to go astray. This is a simple but an important point. Good questioning has a valuable educative role to play in initiating and guiding intellectually virtuous inquiry. The significance of good teacher questioning in education has been recognised and articulated, in a number of different guises, by educational theorists and practitioners (Bloom 1956; Gall 1970; Dillon 1982; Rose and Litcher 1998; Walsh and Sattes 2016). In particular, research has focused on the role that good questioning plays in stimulating learning and initiating class discussion. Benjamin Bloom (1956), for example, an early and prominent advocate of good questioning in education, provides a well-known 'taxonomy of questions', constituting a hierarchy of question types. This hierarchy is intended to be employed by teachers in the classroom in order to advance students through deeper and more sophisticated stages of inquiry, developing specific skills, such as analysis and evaluation, along the way. Good teacher questioning is thus taken to play a vital role in initiating and guiding student inquiry, according to Bloom's taxonomy. This sentiment is echoed throughout both theoretical and practical research on teacher questioning in education. Describing a surge in the use of questions as a pedagogical tool in the 1970s and the early 1980s, for example, Dillon (1982) comments that 'Questions are held to generate more discussion, and higher-order questions are presumed to stimulate higher-order thought and longer responses' (p. 129). More recently, Walsh and Sattes (2016) advocate for teachers' use of 'quality questions' in the classroom, arguing that 'Quality questions focus attention, stimulate thinking, and result in learning at different levels of cognitive complexity' (p. xvi). Whilst research such as this has not, thus far, been framed explicitly in terms of stimulating intellectually virtuous inquiry, the benefits of good teacher questioning in the classroom that are identified throughout this literature can be easily understood in these terms.

As indicated, much of the research on good questioning in education has focused on the teacher's questioning skills and the effects of good teacher questioning on classroom inquiry. The skill involved in good teacher questioning is, in at least one important respect, more nuanced than the skill involved in good student questioning. Specifically, teachers are often required to ask questions to which they already know the answer in order to elicit information that will be valuable for their students' learning. This requires the teacher to make subtle judgements not about what they 
want or need to know, but about the epistemic needs of their students. The key skill, acting competently in order to elicit worthwhile information, remains the same, but it must be performed to a somewhat more sophisticated or nuanced degree. That being said, it is not hard to see how educating for good student questioning can have very similar positive effects in the classroom, as good teacher questioning. Indeed, research that has focused specifically on student questioning suggests a number of additional benefits that emerge as a direct result of placing the emphasis on students, rather than teachers, engaging in good questioning. Positive effects on the retention of information (Ross and Killey 1977), problem-solving abilities and classroom engagement (Blank and Covington 1965), and cognitive development more generally (Chouinard et al. 2007) have all been associated with the quality and/or frequency of student questioning. These benefits speak to the valuable educative role of good questioning. Without good questioning in the classroom, these benefits may not emerge. Again, whilst this research is not framed explicitly in terms of intellectually virtuous inquiry, the positive effects of good student questioning that have been identified in this literature lend support to the claim that good questioning stimulates and maintains intellectually virtuous inquiry. In this way, the intellectual skill of good questioning provides the raw material, so to speak, namely, intellectually virtuous inquiry itself, which helps facilitate the cultivation of intellectually virtuous character.

\section{Good Questioning and Intellectually Virtuous Character}

Once intellectually virtuous inquiry has been initiated in the classroom, opportunities for practising and refining the individual intellectual virtues arise. Good questioning, once again, serves as a valuable pedagogical tool in this regard. We can observe this by taking a closer look at the relationship between good questioning and several of the individual intellectual virtues. I have chosen five familiar intellectual virtues below: attentiveness, intellectual autonomy, intellectual humility, intellectual courage, and inquisitiveness. In each case, good questioning provides an opportunity for the exercise of the virtue, when performed under appropriate virtue-relevant conditions. By 'virtue-relevant conditions', I simply mean conditions relevant to the exercise of the virtue in question. Conditions relevant to the exercise of intellectual autonomy, for example, will often be different from those relevant to the exercise of intellectual humility. Likewise, the same conditions may be virtue-relevant for one person and not for another. If I were particularly nervous about expressing my ideas in public, for example, the conditions relevant for my exercising the virtue of intellectual courage would be different from those relevant for someone who is not nervous about doing so.

In what follows I argue that, when combined with intellectually virtuous motivations and performed in circumstances relevant to the exercise of the virtue in question, the intellectual skill of good questioning can be viewed as itself a form of attentiveness, intellectual autonomy, intellectual humility, intellectual courage, or inquisitiveness. In other words, good questioning is at least sometimes partly constitutive of each of these individual intellectual virtues. As noted above, I follow Zagzebski (1996) and Roberts and Wood (2007) in recognising the necessary and partly constitutive role that intellectual skills play in the exercise of intellectual virtues. As such, my claim is that, at 
least sometimes, the skill of good questioning is the intellectual skill which partly constitutes the intellectual virtues discussed. A person who engages in good questioning may thereby exhibit any one of these intellectual virtues, assuming that they have virtuous motivations and that the appropriate virtue-relevant conditions are in place. Thus, by educating for good questioning, one affords diverse opportunities for exhibiting, practising, and refining (at least) these five intellectual virtues in the classroom. Indeed, it seems plausible that the same could be said for many others, if not all, of the intellectual virtues. An examination of the five listed above, however, will provide sufficient support for the claim that good questioning contributes to the development of several of the individual intellectual virtues and, thereby, contributes to the formation of intellectually virtuous character as a whole. ${ }^{4}$

\subsection{Attentiveness}

I begin with the intellectual virtue of attentiveness. This virtue has not received widespread attention among virtue epistemologists to date, but education practitioners nonetheless typically view it as an important ingredient of classroom learning. The student who is attentive to the teacher, subject matter, or class discussion is more likely to learn and engage in the discussion or task, than the student who is not. Attentiveness both sustains and focuses inquiry. For these reasons, attentiveness is included among the nine Master Virtues at the Intellectual Virtues Academy, a unique charter school in Long Beach, California, established by Jason Baehr. The school explicitly aims to educate for intellectually virtuous character, with the nine Master Virtues incorporated into individual lessons and across the school curriculum. In his discussion of attentiveness, Baehr (2015) identifies three key features of the virtue: the attentive person is (1) 'present' when learning, (2) listens, and (3) 'is quick to notice and is capable of giving sustained attention to important details' (p. 95, emphasis original). According to Baehr's characterisation then, virtuous attentiveness in the classroom is not merely about 'paying attention', to what the teacher is saying. Over and above this, attentiveness is about actively engaging with and carefully attending to the details of one's environment, or the subject matter under consideration, in order to pick out the details that matter in a given context. In this way, the attentive person aids her own learning and advances her inquiries.

This feature of virtuous attentiveness is shared by the intellectual skill of good questioning. In order to be a good questioner, a person must act competently in order to elicit worthwhile information. As such, good questioning requires a person to pay close attention to the details of her informational environment in order to discern which information is worth eliciting and which is not. In this way, good questioning enables a person to effectively navigate her informational environment in order to access the information that

\footnotetext{
${ }^{4} \mathrm{I}$ am aiming for breadth in order to illustrate the significance of good questioning for the formation of intellectually virtuous character, and so I will not attempt to offer a detailed discussion of each of the individual virtues. Nonetheless, the following should provide a sense of how each of these intellectual virtues can manifest as good questioning, and so provide support for the general case. A more detailed examination of good questioning and the individual intellectual virtues would, I believe, be valuable in future work, if the general case proves compelling. In addition, in aiming for breadth, I am not hereby arguing for a unity thesis regarding the intellectual virtues, based on the role that good questioning plays in relation to each of the individual virtues. The following may, however, provide the basis for such a thesis. Again, future work could explore the prospects for this, if the case below proves compelling.
} 
she needs or wants. It is this aspect of good questioning that makes it a form of virtuous attentiveness, when performed under appropriate virtue-relevant conditions and with virtuous motivations. Imagine, for example, a student struggling with a mathematical equation. By encouraging the student to frame and articulate a question that picks out the information he needs in order to move beyond whatever difficulty he is having, his teacher invites him to actively engage with the mathematical equation and attend to the details of the problem and its solution. He must do this, at least to some degree, in order to frame and articulate a question that will competently target the information that he needs. In other words, he must do this in order to ask a good question. It is precisely in attempting to formulate a good question, then, that the student encounters an opportunity to exercise virtuous attentiveness. To be clear, the invitation to engage in good questioning merely provides an opportunity for exercising virtuous attentiveness. The student may still fail to have virtuous motivations and so fail to exhibit the virtue. Nonetheless, being encouraged to formulate a good question (not just any question) presents an opportunity for virtuous attentiveness that may otherwise not have existed because it requires the student to attend closely to the details of the problem that he has encountered and its solution. Once he has done this, and granting him virtuous motivations for doing so, he can be congratulated, not only on asking a good question, but also on asking an attentive one. In common scenarios like this, good questioning is itself a form of virtuous attentiveness. Educating for the intellectual skill of good questioning, thereby, provides opportunities for students to exhibit, practice, and refine the intellectual virtue of attentiveness. ${ }^{5}$

\subsection{Intellectual Autonomy}

Second, we turn to intellectual autonomy. As with attentiveness, intellectual autonomy can be regarded as an important ingredient of classroom learning. The intellectually autonomous person exercises her own will and judgement with respect to her intellectual pursuits. The student who does so plausibly aids her learning by identifying for herself what is required in her particular circumstances to, for example, pursue a line of inquiry or solve a problem. In this way, she avoids irrelevant or unnecessary information, and/or inefficient approaches, and at the same time, becomes less reliant on others to advance her inquiries. Intellectual autonomy both directs inquiry and empowers the inquirer. As another of the nine Master Virtues at the Intellectual Virtues Academy, Baehr (2015) discusses intellectual autonomy, commenting, 'Intellectual autonomy is a willingness and ability to think for oneself' (p. 70). In a similar vein, Roberts and Wood (2007) contend that intellectual autonomy is exemplified by:

the student or researcher who is able to work on his own, where working on his own involves a wise dependence, a willingness and ability to tap the intelligence and knowledge of others as needed (p. 258).

This latter captures the sense in which the intellectually autonomous person not only engages in some form of independent thinking, but also draws on the resources and abilities of others, in an appropriate manner, in order to support her thinking.

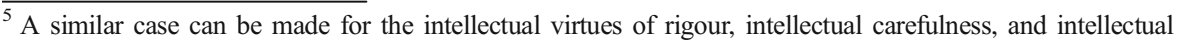
thoroughness.
} 
In the classroom, intellectual autonomy can be observed in students who take the views or ideas of others on board before thinking through a problem for themselves, as well as those who contribute their own solutions, rather than deferring to the solutions of other members of the class, or the teacher. Less overtly, the intellectually autonomous student may be one who simply reflects on a subject matter or thinks through a classmate's solution to a problem, before assenting or corroborating. This intellectually autonomous attitude is also manifested by the student who engages in good questioning. Good questioning requires a person to determine which information in her environment is worth eliciting and which is not. Doing so gives her a degree of control over the information that she takes on board and the information that she avoids or ignores, empowering her to direct her own intellectual pursuits according to her will and judgement. Thus, the good questioner actively determines which information she needs or wants rather than passively and indiscriminately absorbing whatever information is presented.

Return to the student struggling with a mathematical equation. Once again, his teacher can encourage him to frame and articulate a question which picks out the information that he needs in order to move beyond whatever difficulty he is having. In doing so, his teacher invites him to focus on the problem and its solution himself, rather than, say, simply providing him with the solution outright. In this way, the student is given an opportunity to exercise his own will and judgement, determining the information that he already has and the information that he needs, and establishing the best way to pursue the latter: he is invited to think it through for himself. The student must do this in order to frame and articulate a question that will competently target the information that he needs. He must do this in order to ask a good question. It is precisely in attempting to formulate a good question, then, that the student encounters an opportunity to exercise his intellectual autonomy. As before, the student may still fail to exhibit intellectual autonomy. Nonetheless, being encouraged to formulate a good question (not just any question) presents an opportunity for the exercise of this virtue that may otherwise not have existed because it requires the student to actively engage with the problem that he has encountered. In doing so, he can be congratulated on coming up with a means of finding the solution (or at least attempting to do so) himself, even if this ultimately involves relying on the resources and abilities of others to support his inquiry. In common scenarios like this, good questioning is itself a form of intellectual autonomy. Indeed, it is arguably a paradigmatic form of the virtue. Educating for the intellectual skill of good questioning, thereby, provides students with the opportunity to exhibit, practice, and refine the virtue of intellectual autonomy.

\subsection{Intellectual Humility}

Intellectual humility has received notable attention from virtue epistemologists in recent years (Roberts and Wood 2007; Hazlett 2012; Kidd 2015; Whitcomb et al. 2017). Among others, two prominent contrasting characterisations of the virtue have been put forward by Roberts and Wood (2007) and Dennis Whitcomb et al. (2017). These accounts differ on the question of whether intellectual humility is best understood as an absence of vices, specifically, according to Roberts and Wood, the vices of pride, or the presence of a particular ability, namely, the ability to recognise and 'own' one's intellectual limitations, as per Whitcomb et al. I am inclined to favour the latter account, which more obviously incorporates the need for the exercise of skill - if a person fails to recognise and own their intellectual limitations, then they cannot be considered intellectually humble. Whichever 
account one favours, however, it is not hard to appreciate the close relationship between intellectual humility and good questioning. At a basic level, questioning requires a person to recognise that she is lacking some information that she needs or wants and act in order to elicit it. Good questioning requires a person to recognise that the information she is missing is worthwhile and act competently in order to elicit it. It is this combination of recognition and action that aligns good questioning with the limits-owning account of intellectual humility. The good questioner must recognise and 'own' (to use the limits-owning terminology) an important gap in her knowledge or understanding. Doing so will often, perhaps typically, amount to intellectual humility. This is especially apparent given that, for the most part, we are operating under a system that values knowing things highly. Knowledge is, after all, power, as Francis Bacon's (1597) famous Enlightenment adage boldly states. Questioning, however, requires a person to identify precisely what it is that she does not yet know. Good questioning requires a person to identify what it is that she does not yet know, recognise that it is worth knowing, and attempt to find it out. Moreover, given that questioning is, in essence, a social practice, good questioning will frequently require a person to openly and publicly expose the fact that she does not know something that she needs or wants to know, in her attempt to find it out. In any number of situations where there exists a real or perceived expectation that one already does know this or that piece of information, exposing the fact that one does not, by asking a question, can exhibit intellectual humility.

This relationship between good questioning and intellectual humility is particularly clear in the classroom. Rightly or wrongly, students often feel under pressure to have the 'right answers' at their immediate disposal and can be especially unwilling to expose the fact that they do not know or understand something. The student struggling with a mathematical equation, for example, may be unwilling to admit, either to himself or to others, that he is struggling. He may be suffering from a degree of arrogance or pride, and so he fail to notice that his struggle is resulting from his own lack of information or ability. In such a case, the teacher can, as before, encourage the student to frame and articulate a question that picks out the information he needs in order to move beyond whatever difficulty he is having. In doing so, she encourages him to both actively contemplate and consciously expose the fact that he is lacking some information, knowledge, or ability: she encourages him to own his intellectual limitations. She indicates, moreover, that doing so is expected, even commendable, and will be beneficial. In order to frame and articulate a good question, the student must acknowledge and expose the fact that he is lacking something that he needs, and act in order to acquire it: he must own his intellectual limitations. It is precisely in attempting to formulate a good question, then, that the student encounters an opportunity to exercise intellectual humility. Under the appropriate virtue-relevant conditions and assuming virtuous motivations, he can be congratulated on his willingness to recognise and own his intellectual limitations and so on his exercise of intellectual humility. In scenarios like this, good questioning is itself a form of intellectual humility. Educating for the intellectual skill of good questioning, thereby, provides students with the opportunity to exhibit, practice, and refine the virtue of intellectual humility. ${ }^{6}$

\footnotetext{
${ }^{6}$ A similar, albeit in some respects, distinct case can, I think, be made for the intellectual virtue of openmindedness.
} 


\subsection{Intellectual Courage}

The virtue of intellectual courage is, in many respects, closely related to the virtue of intellectual humility. James Montmarquet, in his early influential essay 'Epistemic Virtue' (1987), identifies intellectual courage as a class of virtues, which includes prominently a 'willingness to examine, and even actively seek out, evidence that would refute one's own hypotheses' (p. 484). This feature of intellectual courage is not dissimilar to the limits-owning account of intellectual humility developed by Whitcomb et al. (2017). Roberts and Wood (2007) provide one of the most in-depth discussions of intellectual courage in the virtue epistemology literature. They characterise intellectual courage as 'a power to resist or overcome fears that tend to disrupt one's intellectual functioning' (p. 234). The fear of exposing one's intellectual limitations, to oneself, or, especially, to others, can easily be counted as just such a fear. In some cases, then, it may be precisely in virtue of exercising intellectual humility that a person also exercises intellectual courage. Not only does a person exhibit intellectual humility by recognising and exposing the fact that she is lacking the information that she needs or wants in a given situation, but she also, at least sometimes, simultaneously challenges a real or perceived stigma associated with her lacking of that information. She exposes the fact that she does not know when doing so feels threatening or difficult in some way. Doing so exhibits a degree of intellectual courage.

Again, this relationship between good questioning and intellectual courage is particularly clear in the classroom. The student struggling with a mathematical equation, for example, rather than suffering from arrogance or pride, may feel embarrassed or even ashamed that he is unable to solve the problem without help. An experience such as this can be anxiety-inducing, diminishing a student's confidence in their ability or more general self-esteem. Of course, that will not always be the case, but most people who have either taught or been taught in a classroom will likely recognise this experience from their own or another's perspective. By encouraging the student to frame and articulate a question which picks out the information that he needs in order to move beyond whatever difficulty he is having, his teacher provides a supportive environment in which the student can overcome any fears, anxiety, or stigma he is experiencing. If the student is indeed experiencing these things, then he must overcome them, at least to some degree, in order to frame and articulate a good question, which will, by its nature, expose the fact that he is struggling. It is precisely by asking a good question, then, that the student encounters an opportunity to exercise intellectual courage. In scenarios like this, good questioning is itself a form of intellectual courage. As with the previous three virtues, educating for the intellectual skill of good questioning, thereby, provides students with the opportunity to exhibit, practice, and refine the virtue of intellectual courage.

\subsection{Inquisitiveness}

Of all the intellectual virtues, inquisitiveness bears the closest relationship to the intellectual skill of good questioning. I argue elsewhere that good questioning is, in fact, a defining feature of virtuous inquisitiveness (Watson 2015). As such, one cannot be virtuously inquisitive without engaging in good questioning. It is the skill of good questioning, moreover, that distinguishes virtuous from non-virtuous inquisitiveness. 
One can think of many everyday instances of the latter. A colleague who regularly asks probing questions about one's personal life during board meetings cannot be considered virtuously inquisitive, even though he plausibly satisfies a non-virtuous attribution of inquisitiveness. He is not engaging in good questioning because he is failing to competently elicit worthwhile information: he is attempting to elicit the wrong kind of information, at the wrong time and place. The virtuously inquisitive person, by contrast, competently elicits worthwhile information. Good questioning is a requirement of virtuous inquisitiveness. As such, the intellectual skill of good questioning is not only partly constitutive of virtuous of inquisitiveness in some cases, it is in fact necessary and integral to exercising the virtue in all cases.

Given the integral role that good questioning plays in the exercise of virtuous inquisitiveness, the case in support of educating for good questioning is particularly clear. It is only by educating for good questioning that one can begin to cultivate the intellectual virtue of inquisitiveness. One may, of course, regularly encounter a natural, non-virtuous inquisitiveness in the classroom or wider world. Indeed, this is often the case with young children. However, intellectual virtue requires the exercise of intellectual skill. As such, the intellectual virtue of inquisitiveness cannot merely arise from the persistent asking of questions or even from a characteristic motivation to do so. Rather, it arises from a characteristic motivation to engage in good questioning. This is the intellectual skill required of the virtuously inquisitive person. Simply by educating for this intellectual skill, then, one achieves a crucial part of the task of cultivating the intellectual virtue of inquisitiveness given that good questioning is what distinguishes between virtuous and non-virtuous instances of inquisitiveness.

The student struggling with a mathematical equation can only exhibit virtuous inquisitiveness, about the problem or its solution say, by attempting to frame and articulate a good question. If he does not attempt to engage in good questioning, then he will not even be a candidate for virtuous inquisitiveness (although he may be a candidate for non-virtuous inquisitiveness). By encouraging the student to engage in good questioning, his teacher encourages him to develop an intellectual skill integral to the exercise of virtuous inquisitiveness. He must engage in good questioning in order to do so. What remains, for him to develop the virtue proper, is a characteristic motivation to employ the skill under the appropriate virtue-relevant conditions. This is required, in addition to good questioning, in order for the student to exercise the intellectual virtue of inquisitiveness. It is perhaps plausible that by educating for good questioning, one does begin to inspire or cultivate the motivational component of inquisitiveness. If a student is encouraged to identify worthwhile information, which is significant and relevant to her aims and context, it is plausible that the very process of doing so would generate a kind of inherent interest in the information. In any case, educating for good questioning is an essential component of educating for virtuous inquisitiveness. It is precisely by being encouraged to ask a good question, then, that the student encounters an opportunity to exercise virtuous inquisitiveness. Educating for the intellectual skill of good questioning, thereby, provides students with the opportunity to exhibit, practice, and refine the intellectual virtue of inquisitiveness. 


\section{What Is Left to Do?}

I have argued that educating for the intellectual skill of good questioning both stimulates intellectually virtuous inquiry and contributes to the development of (at least) the intellectual virtues of attentiveness, intellectual autonomy, intellectual humility, intellectual courage, and inquisitiveness. In these respects, educating for good questioning can serve as a valuable tool for intellectual character education. I have not addressed the question of how we can educate for good questioning in this paper. That remains a distinct and challenging undertaking for future research. Rather, my aim has been to present a central line of argument in defence of the claim that we should educate for good questioning: good questioning plays an important role in the formation of an individual's intellectual character. The significance of this extends far beyond the purely veritistic aim of increasing an individual's stock of true beliefs. An individual's intellectual character encompasses their motivation to engage in intellectual pursuits and the manner in which they conduct themselves during intellectual activities, such as public discussion and debate, alongside many other characterological facets. Educating for the intellectual skill of good questioning constitutes one means of cultivating intellectually virtuous character. The task of cultivating intellectually virtuous character, however, will not have been achieved merely by educating for the intellectual skill of good questioning, even if one were to do so successfully. At least, two significant further challenges present themselves.

Firstly, there are numerous ways in which each of the individual intellectual virtues can and do manifest that do not involve or rely on good questioning (with the exception of virtuous inquisitiveness). The attentive person may exercise the virtue by listening carefully in order to extract the information that she needs or wants in order to pursue her line of inquiry. The intellectually humble person may exercise humility by recognising a particular intellectual skill that she lacks in order to achieve a task and allowing someone else to complete it for her. The intellectually courageous person may exercise her courage by asserting an answer, rather than by asking a question. The claim in this paper is not that good questioning is the only form that any of the intellectual virtues can take, or even that it is the primary, or most significant form that they take. Indeed, if a person only ever expressed the intellectual virtues discussed above in the form of good questioning and did not take opportunities to express them in other ways, we would have cause to withhold the attribution of intellectual virtue. They may, perhaps, be deemed an intellectually virtuous questioner, but that is not all there is to being intellectually virtuous. In addition to educating for good questioning, then, a wide range of other skills, both intellectual and non-intellectual, that contribute to the formation of intellectually virtuous character should be cultivated. Skills such as listening, articulation, collaboration, and tact will be required of the intellectually virtuous student. Identifying these skills and their role in the formation of intellectual character is a significant task for intellectual character education. Nonetheless, what is powerful about good questioning as a tool for intellectual character education is both the distinctive role that it plays in the initiation and maintenance of intellectually virtuous inquiry and the fact that it is a form that many, if not all, of the intellectual virtues take at one time or another. As such, it provides a rich resource for cultivating the intellectual virtues, often simultaneously, through intellectually virtuous inquiry. 
Secondly, as noted throughout the discussion, educating for the intellectual skill of good questioning does not amount to educating for intellectually virtuous motivations. Indeed, as we have seen, it is the lack of this motivational component that, in part, distinguishes the skills from the virtues. The motivational component, however, is required in order to cultivate intellectually virtuous character. This highlights a key issue associated with educating for skills, namely, that a student may become highly skilled at a particular task, but remain entirely unmotivated to employ their skill in order to achieve that task. A student may become highly skilled at solving mathematical equations, for example, but demonstrate no significant interest or motivation to do so. Similarly, a student may become a skilled questioner, through training and practice in the classroom, but fail to recognise or harness opportunities to use that skill in the wider world. If so, one may have, in a narrow sense, succeeded in educating for the skill of good questioning, but failed to pass on any of the educational benefits of doing so to the student. A student could, therefore, learn how to be a good questioner but be disinclined or feel unable to use that skill, just like the skilled pianist who no longer plays. Alternatively, they may employ the skill of good questioning for non-virtuous motivations, like the honest man motivated purely by financial gain. In each case, the student will fail to exhibit intellectual virtue in the form of good questioning (even when they are engaged in good questioning). In addition to educating for good questioning, then, intellectual character education requires instilling the basic motivation driving intellectually virtuous inquiry. Elsewhere (Watson 2018), I have suggested that this basic motivation is very close to, if not the same as, virtuous curiosity and have suggested, in outline, a programme for educating for virtuous curiosity. However, the goal of instilling, nurturing, or cultivating intellectually virtuous motivations remains perhaps the most daunting task facing the intellectual character education movement. With that said, it bears repeating that the argument in this paper is not that one educates for intellectually virtuous character only by educating for good questioning. Rather, the claim is that educating for good questioning is a valuable tool that can be used, alongside other tools and practices, in order to cultivate intellectually virtuous character. Insofar as the cultivation of intellectually virtuous character is a desirable educational objective, we should educate for good questioning.

\section{Compliance with Ethical Standards}

Conflict of Interest The author declares that they have no conflict of interest.

Open Access This article is distributed under the terms of the Creative Commons Attribution 4.0 International License (http://creativecommons.org/licenses/by/4.0/), which permits unrestricted use, distribution, and reproduction in any medium, provided you give appropriate credit to the original author(s) and the source, provide a link to the Creative Commons license, and indicate if changes were made.

\section{References}

Aristotle (2011). Nicomachean Ethics. Translated by Robert C. Bartlett and Susan D. Collins. Chicago: Chicago University Press.

Bacon, F. (1597). Meditationes Sacrae and human philosophy. Reprinted by Kessinger Publishing, 1996.

Baehr, J. (2011). The inquiring mind. Oxford: Oxford University Press. 
Baehr, J. (2013). Educating for intellectual virtues: from theory to practice. Journal of Philosophy of Education, 47(2), 248-262.

Baehr, J. (2015). Cultivating good minds: a philosophical \& practical guide to educating for intellectual virtues. Accessed online via http://intellectualvirtues.org/why-should-we-educate-for-intellectual-virtues-2/.

Baehr, J. (2016). Is intellectual character growth a realistic educational aim? Journal of Moral Education, 45(2), 117-131.

Battaly, H. (2006). Teaching intellectual virtues: applying virtue epistemology in the classroom. Teaching Philosophy, 29(3), 191-222.

Battaly, H. (2008). Virtue epistemology. Philosophy Compass, 3(4), 639-663. https://doi.org/10.1111/j.17479991.2008.00146.x.

Blank, S., \& Covington, M. (1965). Inducing young children to ask questions in problem solving. Journal of Educational Research, 59, 21-27.

Bloom, B. (1956). Taxonomy of educational objectives: the classification of educational goals. New York: Longman Green.

Broadie, S. (1991). Ethics with Aristotle. New York: Oxford University Press.

Chouinard, M., Harris, P., \& Maratsos, M. (2007). Children's questions: a mechanism for cognitive development. Monographs of the Society for Research in Child Development, 72(1), 1-129.

Dillon, J. T. (1982). The effect of questions in education and other enterprises. Journal of Curriculum Studies, 14(2), 127-152. https://doi.org/10.1080/0022027820140203.

Driver, J. (2000). Moral and epistemic virtue. In: Knowledge, belief, and character: readings in contemporary virtue epistemology edited by Guy Axtell (pp. 123-134). Maryland: Rowman \& Littlefield.

Driver, J. (2003). The conflation of moral and epistemic virtue. Metaphilosophy, 34(3), 367-383.

Foot, P. 1978. Virtues and vices. In: Virtues and vices and other essays in moral philosophy. Berkeley: University of California Press.

Gall, M. (1970). The use of questions in teaching. Review of Educational Research, 40(5), 707-721.

Grimm, S. (2008). Epistemic goals and epistemic values. Philosophy and Phenomenological Research, LXXVII(3), 725-744.

Hare, W. (2003). Is it good to be open-minded? International Journal of Applied Philosophy, 17(1), $73-87$.

Hazlett, A. (2012). Higher-order epistemic attitudes and intellectual humility. Episteme, 9, 205-223.

Kidd, I. (2015). Educating for epistemic humility. In J. Baehr (Ed.), Intellectual virtues and education: Essays in applied virtue epistemology. New York: Routledge.

Meilaender, G. (1984). The theory and practice of virtue. Notre Dame: University of Notre Dame Press.

Missimer, C. (1990). Perhaps by skill alone. Informal Logic, II(3), 145-153.

Montmarquet, J. (1992). Epistemic virtue and doxastic responsibility. American Philosophical Quarterly, 29(4), 331-341.

Montmarquet, J. (1987). Epistemic virtue. Mind 96(384), 482-497.

Riggs, W. (2010). Open-mindedness. Metaphilosophy, 41(1-2), 172-188.

Roberts, R., \& Wood, J. (2007). Intellectual virtues: an essay in regulative epistemology. Oxford: Oxford University Press.

Rose, S., \& Litcher, J. (1998). Effective questioning techniques: In theory and practice. In L. P. McCoy (Ed.), Studies in teaching (pp. 106-110). Winston Salem: Wake Forest University.

Ross, H., \& Killey, J. (1977). The effect of questioning on retention. Child Development, 48(1), 312-314.

Wallace, J. (1978). Virtues and vices. Ithaca: Cornell University Press.

Walsh, J. A., \& Sattes, B. D. (2016). Quality questioning: research-based practice to engage every learner (second edition). Thousand Oaks: Corwen Press.

Watson, Lani. (2015). What is inquisitiveness. American Philosophical Quarterly, 52(3), 273-288.

Watson, Lani. (2018). Educating for curiosity. In Inan, Ilhan, Watson, Lani, Whitcomb, Dennis, and Yigit, Safiye (Eds.), The moral psychology of curiosity (pp. 293-310). Rowman and Littlefield.

Whitcomb, D., Battaly, H., Baehr, J., \& Howard-Synder, D. (2017). Intellectual humility: owning our limitations. Philosophy and Phenomenological Research, 94(3), 509-539.

Zagzebski, L. (1996). Virtues of the mind: an inquiry into the nature of virtue and the ethical foundations of knowledge. Cambridge: Cambridge University Press. 